\title{
ANALISIS PROBLEMATIKA DAN PENCAPAIAN SISWA DALAM PELAKSANAAN AKM PADA PTM TERBATAS
}

\author{
Fany Lindra Lestari' ${ }^{1}$, Nani Ratnaningsih ${ }^{2}$ \\ 1,2Universitas Siliwangi, Indonesia \\ Email: fanylindralestari@gmail.com ${ }^{\mathbf{1}}$
}

\begin{abstract}
Abstrak
Asesmen Kompetensi Minimum (AKM) merupakan asesmen yang mengukur kemampuan minimal yang dibutuhkan siswa untuk dapat belajar dan merupakan bentuk penyederhanaan dari Ujian Nasional yang begitu kompleks. Adapun materinya hanya terdiri atas tiga yaitu bahasa (literasi), matematika (numerasi), dan penguatan pendidikan karakter. Didukung pada hasil studi PISA menggatakan kemampuan numerasi peserta didik dindonesia masih tergolong rendah. Kemampuan numerasi dapat diartikan sebagai kemampuan seseorang untuk merumuskan, menerapkan, dan menafsirkan matematika berbagai konteks. Tujuan dari penelitian ini adalah untuk menganalisis problematika dan pencapaian siswa dalam pelaksanaan AKM pada Pembelajaran Tatap Muka (PTM) terbatas mata pelajaran matematika kelas V SDN 4 Sukajadi. Penelitian ini menggunakan metode kualitatif deskriptif. Pencapaian hasil belajar siswa kelas V dalam menyelesaikan soal berbasis AKM Numerasi pada PTM terbatas berada dalam kategori rendah karena ada di bawah interval nilai $\leq 40 \%$ yaitu sebesar $18.45 \%$. Dengan demikian, berdasarkan paparan hasil tes dan wawancara yang dilakukan kepada siswa dapat disimpulkan bahwa pencapaian hasil belajar siswa dalam pelaksanaan AKM pada PTM terbatas masih tergolong rendah.
\end{abstract}

Kata kunci : AKM; Pencapaian Siswa; PTM.

\begin{abstract}
Minimum Competency Assessment (AKM) is an assessment that measures the minimum skills required by students to be able to learn and is a simplification of the complex National Examination. The material only consists of three, namely language (literacy), mathematics (numbering), and strengthening character education. Supported by the results of the PISA study, the numeracy skills of Indonesian students are still relatively low. Numerical ability can be defined as a person's ability to formulate, apply, and interpret mathematics in various contexts. The purpose of this study was to analyze the problems and student achievement in the implementation of AKM in Face-to-face Learning (PTM) limited to fifth grade mathematics at SDN 4 Sukajadi. This research uses descriptive qualitative method. The achievement of fifth grade students' learning outcomes in solving AKMbased questions. Numeration at limited PTM is in the low category because it is under the 40\% interval, which is $18.56 \%$. Thus, based on the exposure of the results of tests and interviews conducted to students, it can be concluded that the achievement of student learning outcomes in the implementation of AKM in limited PTM is still relatively low.
\end{abstract}

Keywords: AKM, Student Achievment, PTM. 


\section{Pendahuluan}

Wabah pandemi Coronavirus Disease 2019 (Covid 19) yang melanda Indonesia mengakibatkan seluruh aspek kehidupan sangat terganggu, termasuk pada sektor pendidikan. Begitu juga pada kebijakan yang diberikan berdasarkan Surat Edaran Menteri Pendidikan dan Kebudayaan (Mendikbud) nomor 4 tahun 2020 bahwa Ujian Nasional Berbasis Komputer (UNBK) atau berbasis paper and pencil di gantikan dengan 'Asesmen Kompetensi Minimum (AKM).

Sebagaimana yang telah disampaikan oleh Menteri Pendidikan dan Kebudayaan Nadiem Makarim yang dikutip dari kompas.com pada tahun 2019, Asesmen Kompetensi Minimum (AKM) merupakan asesmen yang mengukur kemampuan minimal yang dibutuhkan siswa untuk dapat belajar dan merupakan bentuk penyederhanaan dari Ujian Nasional yang begitu kompleks. Adapun materinya hanya terdiri atas tiga yaitu bahasa (literasi), matematika (numerasi), dan penguatan pendidikan karakter.

Adapun materi bahasa (literasi) dan matematika (numerasi) pada soal AKM mengacu pada PISA. Berbeda dengan Ujian Nasional (UN) yang pelaksanaannya di akhir jenjang, Asesmen Kompetensi Minimum ini dilakukan di tengah jenjang, yaitu di kelas 4 SD, 8 SMP, dan 11 SMA/SMK. Seperti yang dilansir dari liputan6.com, alasan mengapa AKM akan dilaksanakan pada tengah jenjang menurutnya adalah: (1) memberikan waktu bagi sekolah dan para guru untuk melakukan perbaikan sebelum anak lulus, dan (2) agar tidak bisa dijadikan sebagai alat seleksi untuk siswa yang akan menimbulkan stress bagi anak-anak dan orangtua.

Menurut Ismail (2021) AKM bertujuan untuk meningkatkan kemampuan bernalar dengan menggunakan literasi dan numerasi serta penguatan pendidikan karakter. Namun hasil AKM tidak menjadi ukuran keberhasilan dari tiap individu, sebab AKM memotret dan memetakan mutu sekolah dan pendidikan secara menyeluruh. AKM menyajikan masalah-masalah dengan beragam konteks yang diharapkan mampu diselesaikan oleh peserta didik menggunakan kompetensi literasi membaca dan numerasi yang dimilikinya. AKM dimaksudkan untuk mengukur kompetensi secara mendalam, tidak sekedar penguasaan konten.

Dengan menguji literasi dan numerasi, dalam mengerjakan AKM juga meningkatkan High Order Thinking skills (HOTs) pada peserta didik. (Mahanal, 2019; Masitoh, 2020; Suhaesti, 2017). Keberhasilan peserta didik memahami butir soal dalam AKM, diawali dengan proses pembelajaran dari kerangka pembelajaran yang mendukung. Guru perlu terus berlatih untuk meningkatkan kemampuan berpikir tingkat tinggi pada peserta didik. Stimulus dan rangsangan melalui bacaan dan data sangat menolong dalam berlatih baik guru maupun peserta didik.

Penilaian dalam AKM ini terhimpun dalam 2 rumpun kategori meliputi Literasi dan Numerasi. Lamada et al dalam (Puspaningtyas, 2020) menyatakan bahwa perkembangan literasi menjadi penting untuk diperhatikan, karena literasi merupakan kemampuan awal yang harus dimiliki oleh setiap individu untuk menjalani kehidupan di masa depan. Numerasi merupakan salah satu literasi pada bidang matematika. Ojose mendefinisikan literasi matematika sebagai pengetahuan untuk mengetahui dan menerapkan matematika dasar dalam kehidupan sehari-hari (Hapsari, t.t). Assesmen numerasi dilakukan untuk mengukur sejauh mana peserta didik mampu dalam berpikir menggunakan konsep, dan atau prosedur (Andiani, Hajizah, \& Dahlan, 2020).

Asesmen kemampuan numerasi dilakukan untuk mengukur kemampuan siswa dalam menggunakan konsep dan atau prosedur serta fakta dan atau alat matematika (Maryuliana,2016). Maka dapat diketahui bahwa penggunaan konteks pada AKM Numerasi digunakan untuk mengenali peran matematika dalam kehidupan sehari-hari. 
Menurut Maulidina (Hartatik \& Nafiah, 2020) siswa dengan kemampuan matematika tinggi mampu menggunakan berbagai macam angka atau simbol yang terkait matematika dasar untuk memecahkan masalah matematika, mampu menganalisis informasi dalam bentuk grafik, tabel, bagan dan lainnya dan menggunakan informasi tersebut dalam menyelesaikan masalah. Pengukuran kemampuan numerasi diberikan dalampenyelesaian masalah dalam berbagai jenis konteks yang sesuai. Asesmen yang dibuat masih dalam tahap pengembangan sehingga perlu dilakukan uji coba untukmengkaji perspektif secara teoritismengenai rancangan soal AKM numerasi. AKM Numerasi yang dikembangkan bertujuan untuk mengukur kemampuan berpikir siswa dalam menggunakan konsep, prosedur, fakta, dan alat matematika untuk menyelesaikan masalah sehari-hari pada berbagai jenis konteks yang relevan untuk individu sebagai warga negara Indonesia dan dunia (Pusmenjar, 2020).

Seringkali dalam kehidupan sehari-hari siswa dihadapkan pada permasalahan yang berkaitan dengan penerapan matematika baik mengenai personal, masyarakat, pekerjaan, dan ilmiah. Penguasaan matematika yang baik dapat membantu siswa menyelesaikan masalah tersebut (Johar, 2012). 20 Oleh karena itu, siswa dengan numerasi yang tinggi akan mampu memecahkan masalah-masalah matematika dengan baik, sehingga pembelajaran matematika bermanfaat bagi diri siswa khususnya. Dengan demikian, penyusunan desain soal AKM Numerasi disusun berbasis konteks dalam kehidupan sehari-hari (Cahyanovianty \& Wahidin, 2021). Merujuk pada Han,dkk. (2017), indikator kemampuan numerasi adalah (1) menggunakan berbagai macam angka dan simbol yang terkait dengan matematika dasar untuk memecahkan masalah dalam berbagai macam konteks kehidupan sehari-hari, (2) menganalisis informasi yang ditampilkan dalam berbagai bentuk (grafik, tabel, bagan, diagram dan lain sebagainya) (3) menafsirkan hasil analisis tersebut untuk memprediksi dan mengambil keputusan.

Pelaksanaan Asesmen Kompetensi Minimum (AKM) yang akan diselenggarakan pada jenjang pendidikan sekolah, khususnya dijenjang pendidikan Sekolah Dasar membutuhkan persiapan dalam rangka menyelenggarakannya. Hartatik (2020) menyatakan bahwa kemampuan terendah mahasiswa PPG SD dalam jaringan tahun 2019 dalam menyelesaikan masalah matematika adalah menggunakan simbol atau angka terkait matematika dalam menyelesaikan masalah sehari-hari, hal tersebut dikarenakan banyaknya kesalahan dalam penulisan angka dan simbol untuk menyelesaikan masalah. Selain itu, berdasarkan survei PISA, kemampuan numerasi pada jenjang pendidikan dasar dan menengah masih rendah. Hal ini sejalan dengan

penelitian yang dilakukan oleh (Sari, Lukman, Wahid, 2021) menunjukkan bahwa kemampuan siswa kelas IV Sekolah Dasar dalam menyelesaikan soal geometri pada Asesmen Kompetensi Minimum Numerasi tergolong rendah. Sehingga dapat disimpulkan bahwa siswa memerlukan kesiapan lebih lanjut untuk menghadapi AKM. Peneliti tersebut menyarankan perlu adanya sosialisasi AKM terhadap siswa serta pendampingan khusus dalam mengerjakan variasi latihan soal-soal AKM.

Guru sebagai pendidik menghadapi sebuah tantangan baru di tahun 2021, untuk menjadi fasilitator yang baik bagi peserta didik dalam mempersiapkan diri dalam AKM, di tengah adaptasi pendidikan di masa pandemic covid 19 dengan Pembelajaran Tatap Muka (PTM) terbatas ini. Bagaimana guru dapat menghadapi tantangan ini, adalah dengan pelatihan untuk meningkatkan pemahaman dan keterampilan dalam mendesain pembelajaran yang dapat meningkatkan capaian literasi dan numerasi pada peserta didik.

Berdasarkan pemaparan di atas, peneliti tertarik untuk melakukan penelitian yang berjudul "Analisis Problematika dan Pencapaian Siswa dalam Pelaksanaan Asesmen 
Kompetensi Minimum (AKM) pada Pembelajaran Tatap Muka (PTM) Terbatas". Tujuan dari penelitian ini adalah mendeskripsikan problematika dan pencapaian siswa dalam pelaksanaan AKM kompetensi numerasi pada pembelajaran matematika di Sekolah Dasar.

\section{Metode Penelitian}

Jenis penelitian ini menggunakan pendekataan kualitatif dengan metode deskriptif untuk mendeskripisikan problematika dan pencapaian kemampuan numerasi siswa menyelesaikan soal AKM. Penelitian ini dilakukan di SDN 4 Sukajadi Ciamis. Jawa Barat. Subjek penelitian ini yaitu peserta didik kelas V sebanyak 6 orang sebagai sampel tahun ajaran 2020/2021. Sampel penelitian akan diberikan tes soal AKM yang memuat kemampuan numerasi serta peneliti juga mengambil sampel dengan melakukan wawancara sebagai data pendukung untuk mendeskripsikan problematika yang dimiliki oleh peserta didik. Pada penelitian ini data yang digunakan yaitu tes wawancara dan tes soal AKM yang berjumlah 5 butir soal yang mengacu pada pedoman nasional yang terdiri dari 3 soal Pilihan Ganda (PG), dan 2 soal Uraian. Penyusunan asesmen kompetensi berbasis pada penilaian daya nalar menggunakan bahasa (literasi) dan daya nalar berbasis data angka (numerasi) yang bertolok ukur dari konsep Programme for International Student Assessment (PISA) (Nehru 2019). Adapun kisi-kisi pembuatan soal AKM dibagi menjadi 4 bagian yang akan dijelaskan pada tabel di bawah ini.

Tabel 1. Komponen Numerasi Soal AKM

\begin{tabular}{|c|c|}
\hline Domain & Sub Domain \\
\hline Bilangan & $\begin{array}{l}\text { Representasi, sifat urutan, dan operasi beragam jenis bilangan (cacah, bulat, } \\
\text { pecahan, desimal) }\end{array}$ \\
\hline & Mengenal bangun datar hingga menggunakan volume dan luas permukaan dalan \\
\hline Geometri dan & kehidupan sehari-hari. Juga menilai pemahaman peserta didik tentang pengukuran \\
\hline Pengukuran & $\begin{array}{l}\text { panjang, berat, waktu, volume dan debit serta satuan luas menggunakan satuan } \\
\text { baku. }\end{array}$ \\
\hline Aljabar & $\begin{array}{l}\text { Persamaan dan pertidaksamaan, relasi dan fungsi (termasuk pola bilangan), serta } \\
\text { rasio dan proporsi. }\end{array}$ \\
\hline $\begin{array}{l}\text { Data dan } \\
\text { Ketidakpastian }\end{array}$ & Pemahaman, interpretasi serta penyajian data maupun peluang. \\
\hline
\end{tabular}

Sumber: AKM dan Impikasinya pada Pembelajaran (Pusat Asesmen dan Pembelajaran Balai Penelitian dan Pengembangan dan Perbukuan Kementrian Pendidikan dan Kebudayaan)

Tabel 2. Bentuk Soal AKM

\begin{tabular}{lc}
\hline \multicolumn{1}{c}{ Objektif } & Non-Objektif \\
\hline Pilihan Ganda (hanya 1 jawaban benar) & \\
Pilihan Ganda kompleks (jawaban benar & \\
lebih dari satu) & Essay \\
Menjodohkan & \\
Isian singkat (angka, nama/benda yang & \\
sudah fixed &
\end{tabular}

Sumber: AKM dan Impikasinya pada Pembelajaran (Pusat Asesmen dan Pembelajaran Balai Penelitian dan Pengembangan dan Perbukuan Kementrian Pendidikan dan Kebudayaan)

Prosedur penelitian yang dilakukan adalah pemberian tes tulis berupa soal AKM numerasi dan wawancara. Soal AKM Numerasi yang diberikan mencakup 3 indikator, yaitu: 
Tabel 3. Indikator Numerasi

\begin{tabular}{cl}
\hline No & \multicolumn{1}{c}{ Indikator } \\
\hline 1 & $\begin{array}{l}\text { Mampu menggunakan berbagai macam angka atau simbol yang terkait } \\
\text { dengan matematika dasar dalam menyelesaikan masalah kehidupan sehari- } \\
\text { hari. }\end{array}$ \\
2 & $\begin{array}{l}\text { Mampu menganalisis informasi yang ditampilkan dalam berbagai bentuk } \\
\text { (grafik, tabel, bagan, diagram dan lain sebagainya). } \\
\text { Menafsirkan hasil analisis tersebut untuk memprediksi dan mengambil } \\
\text { keputusan }\end{array}$ \\
\hline
\end{tabular}

Sumber: Han,dkk (2017)

Tes AKM dilakukan secara mandiri untuk mendapatkan hasil yang sesuai dengan tujuan penelitian. Setelah selesai hasil tes tersebut dikumpulkan dan dikoreksi kemudian dikategorikan ke dalam tingkatan kategori rendah, sedang atau tinggi. Berikut ini tabel panduan pengkategorian hasil tes peserta didik.

Tabel 4. Interval Nilai dari Tiap-Tiap Kategori

\begin{tabular}{|c|c|}
\hline Interval Nilai & Kategori \\
\hline$\leq 40$ & Rendah \\
\hline $41-70$ & Sedang \\
\hline$\geq 71$ & Tinggi \\
\hline
\end{tabular}

Sumber: Ma’sum (dalam Khoirudin, A., dkk, 2017)

\section{Hasil dan Pembahasan \\ Temuan penelitian}

Berdasarkan hasil wawancara yang dilakukan di SDN 4 Sukajadi pada siswa kelas V diketahui bahwa problematika yang dialami dalam penerapan Asesmen Kompetensi Minimum pada PTM terbatas diantaranya, siswa mengatakan bahwa belum memahami banyak tentang AKM sehingga mengalami kesulitan dalam proses pengerjaanya. Siswa juga mengatakan bahwa ia mengalami kesulitan dalam memahami soal yang diberikan sehingga hanya menjawab sesuai dengan kemampuan yang dimilikinya. Hasil wawancara dengan siswa yang lainnya memaparkan bahwa ia belum memperoleh informasi AKM Numerasi dengan jelas terutama dalam hal teknik pengerjaan soal Pilihan Ganda Kompleks yang memiliki jawaban lebih dari satu dan tidak menggunakan opsi abjad. Siswa tersebut juga mengatakan bahwa ia baru pertama kali memperoleh dan menyelesaikan soal AKM Numerasi. Ia mengaku kesulitan dalam menjawab soal uraian karena kurang memahami isi soal, beberapa dari soal yang tersaji ada yang belum siswa pelajari di sekolah.

Pencapaian siswa dalam melakukan pembelajaran berbasis AKM Numerasi pada PTM terbatas berada dalam kategori rendah karena ada di bawah interval nilai $\leq 40 \%$ yaitu sebesar 18, 45\%. Dari 5 soal AKM Numerasi yang diberikan kepada siswa, yaitu yang terdiri dari 3 soal Pilihan Ganda (PG), dan 2 soal Uraian siswa hanya mampu menjawab benar 1 soal yaitu pada 1 soal PG (Pilihan Ganda) dengan memperoleh skor sebanyak 2 poin dari total 10 poin. Adapun pada soal uraian, siswa mengalami kesulitan dalam menyelesaikannya disebabkan siswa kurang memahami isi soal dan tidak dapat menjawab secara maksimal.

Dengan demikian, berdasarkan paparan hasil wawancara dan tes yang dilakukan kepada siswa dapat disimpulkan bahwa pencapaian hasil belajar siswa dalam pelaksanaan AKM pada PTM terbatas masih tergolong rendah. Hasil yang diperoleh sesuai dengan penelitian-penelitian serupa yang telah dilakukan untuk menganalisis Asesmen Kemampuan Minimun yang mulai diberlakukan saat ini. 


\section{KESIMPULAN}

Berdasarkan hasil penelitian dapat disimpulkan bahwa problematika yang dialami oleh siswa dalam pelaksanaan Asesmen Kemampuan Minimun khususnya dalam menyelesaikan soal numerasi pada pembelajaran matematika adalah, siswa mengalami kesulitan dalam memahami soal yang diberikan karena belum pernah dipelajari sebelumnya. Pencapaian siswa dalam menyelesaikan soal masih berada dalam kategori rendah yaitu dengan interval nilai $\leq 40 \%$ atau sebesar $18,45 \%$. Peneliti menyarankan guru untuk dapat menyusun asesmen pembelajaran sesuai dengan kondisi siswa selama pandemi. Guru diharapkan dapat melatih siswa untu berpikir kritis sehingga pembelajaran akan berlangsung secara dinamis dan siswa menjadi lebih aktif dalam bertanya dan mengemukakan pendapat mereka mengenai kesulitan-kesulitan yang dialami dalam mengerjakan soal AKM dalam PTM terbatas ini.

\section{DAFTAR PUSTAKA}

AKM dan Implikasinya pada Pembelajaran. (2020). Pusat Asesmen dan Pembelajaran, Badan Penelitian dan Pengembangan dan Perbukuan Kementrian Pendidikan dan Kebudayaan.

Andiani, D., Hajizah, M. N., \& Dahlan, J. A. (2021). Analisis Rancangan Assesmen Kompetensi Minimum (AKM) Numerasi Program Merdeka Belajar. MAJAMATH: Jurnal Matematika dan Pendidikan Matematika, 4(1), 80-90.

Cahyanovianty, A. D., \& Wahidin, W. (2021). Analisis Kemampan Numerasi Peserta Didik Kelas VIII dalam Menyelesaikan Soal Asesmen Kompetensi Minimum (AKM). Jurnal Cendekia: Jurnal Pendidikan Matematika, 5(2), 1439-1448.

Han, W., dkk. (2017). Materi Pendukung Literasi Numerasi. Jakarta: Kementrian Pendidikan dan Kebudayaan.

Hartatik, S., \& Nafiah, N. (2020). Kemampuan Numerasi Mahasiswa Pendidikan Profesi Guru Sekolah Dasar dalam Menyelesaikan Masalah Matematika. Education and Human Development Journal, 5(1), 32-42.

Ismail, S., \& Zakiah, Q. Y. (2021). Policy Analysis Of Implementation Of Minimum Competency Assessment As An Effort To Improve Reading Literacy Of Students In Schools. Paedagoria: Jurnal Kajian, Penelitian dan Pengembangan Kependidikan, 12(1), 83-91.

Johar, R. (2012). Domain Soal PISA untuk Literasi Matematika. Jurnal Peluang, 1(1), 23025158.

Kemdikbud. (2020). Desain Pengembangan Soal Asesmen Kompetensi Minimum 2020

Khoirudin, Ahmad, dkk. (2017). Profil Kemampuan Literasi Matematika Siswa Berkemampuan Matematis Rendah dalam Menyelesaikan Soal Berbentuk PISA, Jurnal Aksioma, Vol. 8, No. 2, November

Mahanal, S. (2019). Asesmen Keterampilan Berpikir Tingkat Tinggi. Jurnal Penelitian dan Pengkajian Ilmu Pendidikan: e-Saintika, 3(2), 51-73.

Maryuliana, S.I. M. I. \&Haviana, S. F. C. (2016). Sistem Informasi Angket Pengukuran Skala Kebutuhan Materi Pembelajaran Tambahan Sebagai Pendukung Pengambilan Keputusan Di Sekolah Menengah Atas Menggunakan Skala Likert. Jurnal Transistor Elektro dan Informatika.1(2), 1-12.

Nehru, Nio Awandha. 2019. “Asesmen Komptenesi Sebagai Bentuk Perubahan Ujian Nasional Pendidikan Indonesia: Analisis Dampak Dan Problem Solving Menurut Kebijakan Merdeka Belajar." Journal of Chemical Information and Modeling 53(9): 1689-99. 
Pusmenjar Kemdikbud. (2020). Asesmen kompetensi minimum. www.youtube.com. https://www.youtube.com/watch?v=ukNxwCtGzZU.

Puspaningtyas, N. D. (2020). Proses Berpikir Lateral Siswa SD dalam Menyelesaikan Masalah Matematika Open-Ended Ditinjau dari Perbedaan Gaya Belajar. MAJAMATH: Jurnal Matematika Dan Pendidikan Matematika, 2(2), 80-86.

Sari,D.R., Lukman, E.N., \& Wahid, M.R. (2021). Analisis Kemampuan Siswa SD Dalam Menyelesaikan Soal Geometri Asesmen Kompetensi Minimum. Jurnal Pendidikan Guru, Vol 2, No. 4 Oktober 2021, 186-190. 